\title{
Gambaran disfungsi ereksi pada pasien dengan benign prostatic hyperplasia (BPH) di Klinik Advent Tikala Manado
}

\author{
${ }^{1}$ Michael B. Tawale \\ ${ }^{2}$ Lydia Tendean \\ ${ }^{2}$ Lusiana Setiawati \\ ${ }^{\mathbf{1}}$ Kandidat Skripsi Fakultas Kedokteran Universitas Sam Ratulangi Manado \\ ${ }^{2}$ Bagian Biologi Fakultas Kedokteran Universitas Sam Ratulangi Manado \\ Email: tawalemichael@yahoo.com
}

\begin{abstract}
Erectile dysfunction (ED) is an inability to achieve an erection sufficient for intercourse with his partner which causes dissatisfaction for both of them. The etiology of ED is classified as psychogenic, organic, drug abuse, and also by post-surgery. Benign prostatic hyperplasia (BPH) is a disease caused by aging. BPH clinical signs usually appear in more than $50 \%$ of men aged $\geq 50$ years. This was a survey-descriptive study with a cross sectional design. Samples were obtained by using purposive sampling technique. Respondents were patients at Efrata Adventist Clinic in Manado. The instrument in this study was modified IIEF-5 questionnaire. The results showed that based on the duration of $\mathrm{BPH}$, respondents who suffered from $\mathrm{BPH}>3$ years were as many as $75.0 \%$ and $<1$ year were $7.1 \%$. Based on the ages, respondents of $61-70$ years were 46.5 and of $41-50$ years were $7.1 \%$. The erectile dysfunction of respondents was classified as moderate $42.9 \%$, mildmoderate $32.1 \%$, severe $17.9 \%$, and mild $7.1 \%$. Conclusion: Most of the erectile dysfunction with BPH $>3$ years was classified as moderate.
\end{abstract}

Keywords: erectile dysfunction, $\mathrm{BPH}$

\begin{abstract}
Abstrak: Disfungsi ereksi (DE) yaitu suatu ketidakmampuan untuk mencapai ereksi yang cukup untuk melakukan senggama bersama pasangannya sehingga menimbulkan ketidakpuasan diantara keduanya. Etiologi DE diklasifikasikan menjadi psikogenik, organik, penyalahgunaan obat-obatan dan juga oleh pasca tindakan bedah. Benign prostatic hyperplasia $(\mathrm{BPH})$ adalah penyakit yang disebabkan oleh penuaan. Tanda klinis BPH biasanya muncul pada lebih dari 50\% laki-laki yang berusia 50 tahun ke atas. Jenis penelitian ialah survei deskriptif-observasional dengan desain potong lintang. Pengambilan sampel dilakukan dengan teknik purposive sampling pada seluruh pasien di Klinik Advent Efrata Tikala Manado. Variabel penelitian ialah pasien BPH di Klinik Advent Tikala Manado. Instrumen penelitian menggunakan kuesioner IIEF-5 yang telah dimodifikasi. Hasil penelitian mendapatkan berdasarkan lama menderita $\mathrm{BPH}$, responden yang menderita $\mathrm{BPH}$ $>3$ tahun sebesar 75,0\%; 1-2 tahun sebesar 17,9\%; dan $<1$ tahun sebesar 7,1\%. Berdasarkan usia responden berusia 61-70 tahun sebesar 46,5\% dan 41-50 tahun sebesar 7,1\%. DE pada BPH paling banyak termasuk klasifikasi sedang $(42,9 \%)$, diikuti ringan-sedang $(32,1 \%)$, berat $(17,9 \%)$ dan ringan $(7,1 \%)$. Simpulan: Sebagian besar pasien DE dengan BPH $>3$ tahun termasuk dalam klasifikasi sedang.
\end{abstract}

Kata kunci: disfungsi ereksi, BPH

Disfungsi ereksi (DE) yaitu suatu ketidakmampuan untuk mencapai ereksi yang cukup untuk melakukan senggama bersama pasangannya sehingga menimbulkan ketidakpuasan bagi keduanya. Berdasarkan etiologinya DE dapat diklasi- 
fikasikan menjadi disfungsi ereksi yang disebabkan oleh psikogenik, organik, penyalahgunaan obat-obatan dan juga oleh pasca tindakan bedah. ${ }^{1}$ Benign prostatic hyperplasia $(\mathrm{BPH})$ adalah penyakit yang disebabkan oleh penuaan. ${ }^{2}$ Tanda klinis BPH biasanya muncul pada lebih dari $50 \%$ laki-laki yang berusia 50 tahun ke atas. ${ }^{3}$ Frekuensi kejadian BPH meningkat secara progresif seiring usia mulai dari usia 41-50 tahun (20\%), 51-60 tahun (50\%), hingga mencapai $(90 \%)$ pada usia 80 tahun ke atas. ${ }^{1}$

Disfungsi ereksi didefinisikan sebagai ketidakmampuaan yang konsisten untuk mendapatkan atau mempertahankan ereksi dan memuaskan hubungan seksual. Pembagian DE dikelompokkan menjadi lima kategori penyebab yaitu: psikogenik, organik, hormonal, farmakologi, traumatik pasca bedah. ${ }^{2}$ Fazio dan Brock mengklasifikasikan penyebab DE sebagai berikut: ketuaan, gangguan psikologis (depresi, ansietas), gangguan neurologik (penyakit serebral, trauma spinal, penyakit medula spinalis, neuropati, trauma nervus pudendosus), penyakit hormonal (hipo-gonadisme, hiperprolaktinemia, hiper atau hipotiroidisme, sindrom Cushing, penyakit Addison, penyakit vaskuler, obat-obatan (antihipertensi, antidepresan, esterogen, antiandrogen, digoksin), kebiasaan, (pemakai marijuana, alkohol, narkotik, merokok), dan penyakit-penyakit lain (diabetes melitus, gagal ginjal, hiperlipidemia, hipertensi, penyakit paru obstruksi kronis). ${ }^{2}$

Faktor risiko DE ialah sindrom metabolisme, gejala saluran kemih bagian bawah akibat BPH, penyakit kardiovaskular, merokok, kondisi sistem saraf pusat, trauma spinalis, depresi, stres, gangguan endokrin, dan diabetes. ${ }^{2,3}$

World Health Organization (WHO) menyebutkan hak untuk sehat secara seksual (sexual health) merupakan hak asasi manusia. ED merupakan gangguan/ disfungsi seksual pria yang paling sering dijumpai. ED memengaruhi sekitar 14-30\% pria berusia lebih dari 18 tahun, 30\%-40\% pria yang aktif secara seksual, dan $75 \%$ pria di saat tertentu di dalam kehidupannya.
Di seluruh dunia terdapat sekitar 22-38\% penderita ED. Menurut Carson dan Gunn sekitar 25\%-40\% dari semua pria menderita DE. Beberapa sumber bahkan menyebutkan $30-75 \%$ dari semua pria di dunia menderita ED. ${ }^{2}$

Benign prostatic hyperplasia $(\mathrm{BPH})$ termasuk penyakit yang disebabkan oleh penuaan. Tanda klinis BPH biasanya muncul pada lebih dari $50 \%$ laki-laki yang berusia 50 tahun ke atas. Hiperplasia prostatik berupa pertumbuhan nodul-nodul fibroadenomatosa majemuk dalam prostat; pertumbuhan tersebut dimulai dari bagian periuretral sebagai proliferasi yang terbatas dan tumbuh dengan menekan kelenjar normal yang tersisa. $^{3}$ Penyebab BPH kemungkinan berkaitan dengan penuaan dan disertai dengan perubahan hormon. Terdapat teori bahwa estrogen/androgen yang lebih tinggi akan merangsang hiperplasia jaringan prostat. $^{4-7}$ Pembesaran prostat tergantung pada androgen dihydrotestosterone (DHT). Dalam kelenjar prostat, type II 5-alphareductase memetabolisme testosteron. DHT bekerja bukan secara sistemik, namun lokal. DHT terikat pada reseptor androgen yang berpotensi menyebabkan BPH. ${ }^{1}$ Faktor risiko terjadinya $\mathrm{BPH}$ ialah kadar hormon testosteron yang tinggi, usia, ras, riwayat keluarga, obesitas, pola diet, aktifitas seksual, kebiasaan merokok, alcohol, olah raga, diabetes melitus. ${ }^{4,5}$

\section{METODE PENELITIAN}

Jenis penelitian ini ialah deskriptifobservasional dengan desain potong lintang. Penelitian dilakukan di Klinik Advent Efrata Tikala Manado padaJanuari 2015 - Maret 2015. Pengambilan sampel dilakukan dengan teknik purposive sampling pada seluruh responden yang memenuhi kriteria inklusi. Data primer dalam penelitian ini diperoleh dari observasi dan wawancara langsung pada responden BPH di Klinik Advent Efrata Tikala Manado.

Variabel penelitian ialah pasien $\mathrm{BPH}$ di Klinik Advent Tikala Manado. Instrumen penelitian menggunakan kuesioner IIEF-5 yang telah dimodifikasi 
dengan klasifikasi sebagai berikut: Berat jika jumlah skor 1-6; sedang jika jumlah skor 7-12; ringan-sedang jika jumlah skor 13-18; ringan jika jumlah skor 19-24; dan bukan disfungsi ereksi jika jumlah skor $\geq 25$.

\section{HASIL PENELITIAN DAN \\ BAHASAN}

Penelitian tentang gambaran disfungsi ereksi pada BPH dilakukan pada 28 responden yang memenuhi kriteria penelitian. Hasil penelitian diuraikan dalam bentuk tabulasi. Tabel 1 menunjukkan bahwa jumlah terbanyak pada responden disfungsi ereksi pada BPH berdasarkan usia adalah 61-70 tahun yaitu sebesar $46,5 \%$, dan yang paling sedikit antara usia 41-50 tahun yaitu sebesar 7,1\%.

Tabel 1. Distribusi responden disfungsi ereksi pada BPH berdasarkan usia.

\begin{tabular}{ccc}
\hline Usia & $\mathbf{N}$ & $\mathbf{\%}$ \\
\hline $41-50$ & 2 & 7,1 \\
$51-60$ & 3 & 10,7 \\
$61-70$ & 13 & 46,5 \\
$71-80$ & 10 & 35,7 \\
Jumlah & 28 & 100 \\
\hline
\end{tabular}

Tabel 2 menunjukkan bahwa berdasarkan lama responden menderita BPH yaitu lebih dari 3 tahun sebesar $75 \%$, dan kurang dari 1 tahun sebesar 7,1\%.

Tabel 2. Distribusi responden berdasarkan lama menderita $\mathrm{BPH}$.

\begin{tabular}{ccc}
\hline Lama & $\mathbf{N}$ & $\mathbf{\%}$ \\
\hline$<1$ tahun & 2 & 7,1 \\
$1-2$ tahun & 5 & 17,9 \\
$>3$ tahun & 21 & 75,0 \\
Jumlah & 28 & 100 \\
\hline
\end{tabular}

Tabel 3 menunjukan bahwa disfungsi ereksi paling banyak terdapat pada klasifikasi sedang yaitu sebesar $42,9 \%$, dan yang paling sedikit pada klasifikasi ringan yaitu sebesar $7,1 \%$.

Tabel 4 menunjukan bahwa responden yang mengalami disfungsi ereksi dengan lama BPH paling banyak pada pasien dengan BPH lebih dari 3 tahun dengan jumlah 16 responden, dengan klasifikasi sedang sebesar $42,9 \%$.

Table 3. Presentase responden BPH yang mengalami disfungsi ereksi berdasarkan klasifikasi.

\begin{tabular}{lcccccc}
\hline Disfungsi ereksi & \multicolumn{4}{c}{ Usia (tahun) } & N & \multirow{2}{*}{} \\
\cline { 2 - 5 } & $\mathbf{4 1 - 5 0}$ & $\mathbf{5 1 - 6 0}$ & $\mathbf{6 1 - 7 0}$ & $\mathbf{7 1 - 8 0}$ & & \\
\hline Normal & 0 & 0 & 0 & 0 & 0 & 0 \\
Ringan & 1 & 0 & 0 & 1 & 2 & 7,1 \\
Ringan-sedang & 1 & 1 & 4 & 2 & 9 & 32,1 \\
Sedang & 0 & 2 & 7 & 4 & 12 & 42,9 \\
Berat & 0 & 0 & 2 & 3 & 5 & 17,9 \\
\hline Jumlah & 2 & 3 & 13 & 10 & 28 & 100 \\
\hline
\end{tabular}

Tabel 4. Presentase responden disfungsi ereksi berdasarkan klasifikasi dengan lama BPH.

\begin{tabular}{lcccc}
\hline Disfungsi & \multicolumn{3}{c}{ Lama BPH } & \multirow{2}{*}{ Total } \\
\cline { 2 - 4 } ereksi & $<\mathbf{1}$ tahun & $\mathbf{1 - 2}$ tahun & $>\mathbf{3}$ tahun & \\
\hline Normal & $0(0 \%)$ & $0(0 \%)$ & $0(0 \%)$ & $\mathbf{0}(0 \%)$ \\
Ringan & $2(7,1 \%)$ & $0(0 \%)$ & $0(0 \%)$ & $\mathbf{2}(\mathbf{7 , 1} \%)$ \\
Ringan-sedang & $1(3,6 \%)$ & $3(10,7 \%)$ & $5(17,9 \%)$ & $\mathbf{9 ( 3 2 , 1 \% )}$ \\
Sedang & $1(3,6 \%)$ & $4(14,3 \%)$ & $7(25,0 \%)$ & $\mathbf{1 2}(\mathbf{4 2 , 9} \%)$ \\
Berat & $0(0 \%)$ & $1(3,6 \%)$ & $4(14,3 \%)$ & $\mathbf{5 ( 1 7 , 9 \% )}$ \\
Total & 4 & 8 & 16 & $28(100 \%)$ \\
\hline
\end{tabular}




\section{BAHASAN}

Pada penelitian ini jika dilihat dari lama BPH yang dialami, maka responden yang menderita $\mathrm{BPH}>3$ tahun sebesar $75,0 \%$, dan yang $<1$ tahun menjadi yang paling sedikit yaitu sebesar $7,1 \%$ pada 28 responden yang bersedia pada penelitian ini (Tabel 2). Jumlah terbanyak pada responden disfungsi ereksi pada $\mathrm{BPH}$ berdasarkan usia adalah 61-70 tahun yaitu sebesar $46,5 \%$, dan yang paling sedikit antara usia 41-50 tahun yaitu sebesar 7,1\% (Tabel 1). Presentase disfungsi ereksi pada $\mathrm{BPH}$ berdasarkan klasifikasi paling banyak masuk dalam klasifikasi sedang (42,9\%), ringan-sedang $(32,1 \%)$, berat $(17,9 \%)$ dan ringan $(7,1 \%)$ (Tabel 3). Hasil penelitian memperlihatkan bahwa disfungsi ereksi berdasarkan klasifikasi dan lamanya $\mathrm{BPH}$ juga memengaruhi berat-ringannya disfungsi seksual yang terjadi pada responden penelitian ini, baik pada disfungsi ereksi ringan, ringan-sedang, sedang dan berat. Disfungsi ereksi yang terjadi pada responden yang menderita $>3$ tahun (16 responden) paling banyak masuk dalam klasifikasi sedang sebesar $42,9 \%$ (Tabel 4).

Melalui penelitian ini diketahui disfungsi ereksi berhubungan dengan $\mathrm{BPH}$ sehingga bila penanganan $\mathrm{BPH}$ ditangani dengan baik maka dapat dicapai hak untuk sehat secara seksual (sexual health) yang merupakan hak asasi manusia seperti dikemukakan oleh World Health Organization (WHO). ${ }^{(2)}$

\section{SIMPULAN}

Dari hasil penelitian mengenai disfungsi ereksi pada pasien benign prostate hyperplasia (BPH) dapat disimpulkan bahwa disfungsi ereksi paling banyak ditemukan pada yang berusia 60-70 tahun, lama menderita BPH >3 tahun, dengan klasifikasi sedang

\section{DAFTAR PUSTAKA}

1. Nadia F, Zuhirman, Suyanto. Hubungan benign prostate hypertrophy dengan disfungsi ereksi di RSUD Arifin Achmad Provinsi Riau. Jurnal Fakultas Kedokteran Universitas Riau. 2014:1(2):1-12.

2. Dito A. (2012). Ejakulasi Dini. Jurnal Fakultas Kedokteran Universitas Palangka Raya/RSU. PKU Muhammadiyah Palangka Raya. 2015;39:1-5.

3. Nugroho BU, Birowo $\mathbf{P}$, Rasyid $\mathbf{N}$, Taher A. Disfungsi ereksi pada pasien benign prostatic hyperplasia dengan lower urinary tract symptoms. Jurnal Ilmu Bedah Indonesia. 2012;40(1):13-5.

4. Price AS, Wilson ML. Patofisiologi Konsep Klinis Proses-Proses Penyakit vol 2 (6th ed). Jakarta: EGC, 2005.

5. Rizki A. (2010). Faktor-faktor pembesaran prostat jinak (Studi kasus di RS. Kariandi, RSI Sultan Agung, RS. Roemani Semarang). Epidemiologi, Prosiding Seminar Nasional Unimus 2010; p. 1-5.

6. Park HJ, Won JJ, Sorsaburu S, Rivera PD, Lee SW. Urinary tract symptoms (LUTS) secondary to benign prostatic hyperplasia (BPH) and LUTS/BPH with erectile dysfunction in asian men: a systematic review focusing on tadalafil. World J Mens Health. 2013;31(3):193-207.

7. Samsul M. (2010). Sindrom metabolik dan defisiensi testosteron. PharaMedika, 2010;2:165-70. 